\title{
Probiotics for treatment and primary prevention of allergic diseases and asthma: looking back and moving forward
}

\author{
Christina E. West, Maria Jenmalm, Anita L. Kozyrskyj and Susan L. Prescott \\ Journal Article
}

\section{Tweet}

N.B.: When citing this work, cite the original article.

This is an electronic version of an article published in:

Christina E. West, Maria Jenmalm, Anita L. Kozyrskyj and Susan L. Prescott, Probiotics for treatment and primary prevention of allergic diseases and asthma: looking back and moving forward, EXPERT REVIEW OF CLINICAL IMMUNOLOGY, 2016. 12(6), pp.625-639.

EXPERT REVIEW OF CLINICAL IMMUNOLOGY is available online at informaworldTM:

http://dx.doi.org/10.1586/1744666X.2016.1147955

Copyright: Taylor \& Francis: STM, Behavioural Science and Public Health Titles - No Open Select

$$
\text { http://www.tandf.co.uk/journals/default.asp }
$$

Postprint available at: Linköping University Electronic Press

http://urn.kb.se/resolve?urn=urn:nbn:se:liu:diva-133551

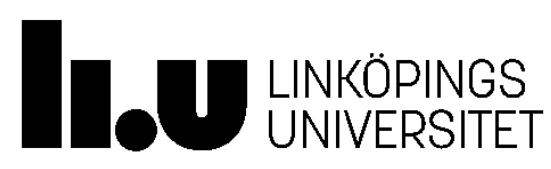


Publisher: Taylor \& Francis

Journal: Expert Review of Clinical Immunology

DOI: $10.1586 / 1744666 X .2016 .1147955$

Probiotics for treatment and primary prevention of allergic diseases and asthma: looking back and moving forward

Christina E West ${ }^{1,2 \star}$, Maria C Jenmalm ${ }^{1,3}$, Anita L Kozyrskyj ${ }^{1,4}$, Susan L Prescott ${ }^{1,5}$

${ }^{1}$ International Inflammation (in-FLAME) network of the World Universities Network

${ }^{2}$ Department of Clinical Sciences, Pediatrics, Umeå University, 90185 Umeå, Sweden

${ }^{3}$ Department of Clinical and Experimental Medicine, Linköping University, SE-581 85 Linköping Sweden

${ }^{4}$ Department of Pediatrics, Faculty of Medicine \& Dentistry, University of Alberta 3-527, Edmonton Clinic Health Academy (ECHA) 11405-87 Avenue, Edmonton, AB T6G 1C9 Alberta, Canada

${ }^{5}$ School of Paediatrics and Child Health Research, University of Western Australia, PO Box D184, Princess Margaret Hospital, Perth WA 6001, Australia.

\section{${ }^{*}$ Corresponding author}

Dr Christina West

Department of Clinical Sciences, Pediatrics, Umeå University, 90185 Umeå, Sweden

Tel: $(+46) 907852216$

Fax:(+46) 90123728

E-mail: christina.west@umu.se 


\section{Summary}

Microbial ecosystems cover the surface of the human body and it is becoming increasingly clear that our modern environment has profound effects on microbial composition and diversity. A dysbiotic gut microbiota has been associated with allergic diseases and asthma in cross-sectional and observational studies. In an attempt to restore this dysbiosis, probiotics have been evaluated in randomized controlled trials. Here, we review treatment and primary prevention studies, recent meta-analyses, and discuss the current understanding of the role of probiotics in this context. Many meta-analyses have shown a moderate benefit of probiotics for eczema prevention, whereas there is less evidence of a benefit for other allergic manifestations. Because of very low quality evidence and heterogeneity between studies, specific advice on the most effective regimens cannot yet be given - not even for eczema prevention. To be able to adopt results into specific recommendations, international expert organizations stress the need for well-designed studies.

Keywords: diversity; dysbiosis; eczema; gut microbiome; hygiene hypothesis; primary prevention; probiotic 


\section{Introduction}

Our health depends on the health of our environment, and the biodiversity that sustains all life. The human body is home to many vast and diverse microbial ecosystems, which cover all of our inner and outer surfaces. We are only just beginning to understand how the composition and metabolic function of mutualistic microbes affect almost all aspects of our health - ranging from immune development and barrier defence, to our metabolism, appetite regulation, mood and behaviour. Large-scale disruptions of our natural environment by human activity through pollution, modern agricultural practices, sterile and processed foods, and the other collective effects of human activity, are affecting fragile ecosystems - including the human microbiome. Similarly, changing patterns of human behaviour towards more sedentary indoor lifestyles with progressive disconnection from nature are also contributing to the 'dysbiotic drift' which has been implicated in rising rates of allergy, metabolic disease, and mental ill health.

The year 2016 marks 100 years since the death of Elie Metchnikoff, who first pioneered the concept that disruption of intestinal microorganisms contributes to human ill-health, and that restoration of lactic acid bacteria with fermented foods can restore health [1]. Although pioneer researcher Dubos went on to publish dozens of experimental studies implicating the intestinal microbiota in multiple aspects of health [summarized in 2], this work has gone largely overlooked. As early as 1962 Dubos concluded that "Metchnikoff's concepts of intestinal intoxication may have some factual basis after all" and that he was "inclined to believe that the usual intestinal flora is an expression of man's total environment, and that its control may turn out to have as profound effects on the well-being of human infants and adults as it has on the growth of mice and farm animals" [3]. Although overlooked by history, these concepts are now fundamental in the search for strategies to overcome the growing burden of immune, metabolic, and mental disorders which are inextricably linked to modern environmental changes including declining biodiversity and unhealthy obesogenic dietary 
practices [4]. There is now enormous concern that each 'cleaner' generation may be starting life with a smaller endowment of ancient microbes than the last [5]. Given the critical importance of the microbiota in early immune maturation and metabolic programming, this has been emerging as a likely culprit in rising rates of immune dysregulation and the growing propensity for inflammation, [recently reviewed in 6]. The children of today are the third generation to live in the 'age of antibiotics', and the third generation to consume 'fast food' and highly processed foods - a major factor in influencing microbial composition, diversity and metabolic activity [7]. Efforts to restore this remain a challenge when we 'don't even know what we've lost'. Probiotics and prebiotics have been the primary avenues to pursue this, although this has been limited by a still rudimentary understanding of the complexity of the microbiota and how to optimally influence its assembly in early life. Here, we review studies using probiotics in the treatment and primary prevention of allergic diseases and asthma, with an emphasis on human studies.

\section{Gut microbiota development}

The microbiota plays a fundamental role in normal immune development and regulation [8]. No animal has evolved independently of microbial symbionts and the neonatal immune system seems to have evolved to require diverse developmental signals from microbes to mature normally [8-10]. The first interactions between the microbiota and the host may occur already in utero $[11,12]$. Thus, recent evidence contradicts the "sterile womb" paradigm, proposing that the sterile fetus first acquires bacteria when passing the birth canal $[11,12]$. Any microbial presence in utero has been assumed to be dangerous for the fetus and intrauterine infections can lead to preterm birth [13]. Intracellular bacteria were histologically demonstrated in the basal plate, the peripheral region of the placenta on the maternal side in contact with the uterine wall, at a similar rate in preterm and term pregnancies without overt infection, however [13]. Furthermore, extensive deep sequencing studies recently identified a low abundance but metabolically rich placental microbiome present in normal healthy pregnancies at term [11]. This microbiome was primarily composed of non-pathogenic 
commensal microbiota from the Firmicutes, Proteobacteria, Bacteroidetes, Actinobacteria, Tenericutes and Fusobacteria phyla [11]. As compared with the microbiomes from the vagina, gut, skin, nose and mouth, the placental microbiome was characterized by higher abundance of Proteobacteria (with E. coli the most commonly detected species) and the unique presence of Tenericutes, including Mycoplasma and Ureaplasma [11]. Unexpectedly, the placental microbiome was more closely related to the mouth microbiome than the vaginal, gut or other body microbiomes, possibly suggesting that the placental microbiome could be partially established by hematogenous spread of oral microbiota [1, 14].

As gut associated bacteria such as Enterococcus faecium have been isolated from umbilical cord blood of healthy neonates born by elective Cesarean section [15], it has also been suggested that maternal bacteria may travel to the placenta via the bloodstream after translocation over the gut epithelium [12, 14]. Dendritic cells may facilitate transport of maternal bacteria by taking up luminal bacteria intracellularly and then migrating to lymphoid organs [12]. In murine studies, transmission of orally administered labeled bacterial strains from the mother to her fetus can be demonstrated [15], and pregnancy and lactation is associated with enhanced translocation of gut bacteria to mesenteric lymph nodes [14]. Evidence for microbial maternal transmission is becoming increasingly widespread across the animal kingdom [12]. This may provide the offspring with important microbes at birth, imprinting the offspring microbiota and immune system in preparation for the much larger inoculum transferred during vaginal delivery [10, 12, 16-22] and breastfeeding [10, 12, 14, 17,23] (Figure 1), and may have shaped the microbiome composition in animal species over evolutionary time. "Heirloom" microbes received from the mother may be uniquely evolved to the offspring's genotype and vertical as compared with horizontal transmission may increase the chance for optimal mutualism [12]. Thus, Caesarean section delivery, which is performed with increasing rates worldwide and may increase the risk for development of allergy and other immune mediated diseases [10], potentially disrupts the opportunities for the microbiota to be transferred from a mother to her baby to provide a genetically tailored microbiota and 
optimal mutualism [12]. The potential for vertical transmission of ancestral microorganisms to the next generation is also decreased, particularly when horizontal transmission is also diminished by factors such as antibiotics, antibacterial agents and decreased family size [5]. Delivery by Caesarean section has been associated with persistent changes in the gut microbiota of children followed up to one $[17,18]$ and two [20] years of age. The disruptions in infant gut microbial ecology caused by Caesarean section delivery include a reduced abundance of the genus Bacteroides [16-21] and a decreased diversity of the Bacteroidetes phylum [20]. A reduced abundance and diversity of bifidobacteria has also been observed in children delivered by Caesarean section in some studies [18, 19, 24]. Furthermore, increased occurrence of colonization with Clostridium difficile, an opportunistic pathogen, expanding when gut microbiota niches are vacant, has been reported among infants born by Caesarean section [21, 22].

After birth, the early colonizers are accompanied by externally acquired species as the infant gut microbiota diversity increases with age $[17,18,20,25]$. During this early phase, the gut microbiota composition is highly dynamic within and between infants

$[20,25,26]$. As the neonatal gut initially contains oxygen, a large proportion of the early colonizers are aerotolerant facultative bacteria, including Enterobacter, Lactobacillus, Staphylococcus and Streptococcus genera [26]. When the bacteria consume the oxygen in the intestine, strict anaerobes, including Bifidobacteria, Bacteroides, Eubacteria and Clostridia, begin to dominate at one week of age $[18,26]$.

Apart from the delivery mode, another strong influence shaping the developing infant gut microbiota relates to nutritional factors in early life. Breastfeeding provides a secondary route of maternal microbial transmission [12, 14, 17, 23]. Gut microbiota diversity increases following weaning and introduction of solid food, with enhanced colonization of butyrate producers, including Bacteroides and certain Clostridium species [18]. The maternal oral microbiota may have represented another source of vertical microbial transmission during 
evolution, e $g$ by the mother chewing up solid foods and then feeding the resulting mash to the infant. In summary, vertical transmission of microbial symbionts from mother to offspring occurring through a variety of pre-, peri- and postnatal routes may crucially influence infant microbiota and immune development (Figure 1).

\section{Immune system maturation parallels the gut microbiota development}

Interactions occurring between the microbiota and the host during critical time windows of developmental plasticity may exert particularly long lasting effects [8, 10]. Thus, several immunological abnormalities observed in germ free mice can only be reversed if the animals are colonized with symbiotic microbes during the perinatal period, whereas later colonization fails to reverse homeostasis. Normalization of excessive allergen induced Th2 and IgE responses in germ free mice seems to require a critical colonization time window, both after oral $[27,28]$ and airway [29] exposure to allergens. Furthermore, reversal of Th2 cytokine dependent oxazolone-induced colitis in mice via regulation of iNKT cell homeostasis is only obtained after neonatal colonization [29] or even maternal colonization throughout gestation [30], with similar findings observed for intestinal proinflammatory responses $[31,32]$ and LPS-induced proinflammatory responses in mesenteric lymph node cells [33].

While it is not clear if a similar critical colonization time window for optimal immune maturation exists in humans, early life events occurring during critical periods of immune development can have long-term impact on development of immune mediated diseases [9, 10, 34]. Even prenatal exposures may shape immune developmental trajectories. For example, maternal exposure to a traditional farm environment during pregnancy protects against allergic sensitization and disease, whereas exposures during infancy alone have weaker or no effect at all [35]. Furthermore, a combined prenatal and postnatal supplementation seems to be important for the preventive effect of probiotics on infant eczema [10, 34, 36-41], (Table 1). It is thus becoming increasingly evident that the maternal microbial environment during pregnancy is important in childhood immune programming [9, 
$10,14,34]$. The close immunological interaction between the mother and her offspring during pregnancy [9, 42] provides enormous opportunities for the maternal microbial environment to influence the immune development of her offspring, potentially via epigenetic effects $[9,10$, 14, 42]. Starting probiotic supplementation already from the second trimester of pregnancy, when circulating fetal $\mathrm{T}$ cells have developed, may have a more powerful allergy preventive effect than observed in previous studies where probiotics were administered from the third trimester [10, 34, 36-41]. Furthermore, the impact on maturation of innate and adaptive immune regulatory responses $[43,44]$ may be more long lasting with a prolonged prenatal probiotic intervention strategy, combined with postnatal supplementation.

The Th2-skewed state of the neonatal immune system [45] is likely) a consequence of the intrauterine immune milieu during pregnancy [9]. This neonatal Th2-skewing is even more marked in infants later developing allergic disease $[45,46]$, supporting that the prenatal immune environment can influence allergy development [9, 42]. The neonatal Th2-bias should then develop toward a more balanced immune phenotype, including maturation of Th1-like responses [45] as well as appropriate development of regulatory $T$ cell [10] and protective mucosal IgA responses [47]. A failure of Th2-silencing during maturation of the immune system may underlie development of Th2-mediated allergic disease [45]. Appropriate microbial stimulation, both pre- and postnatally, may be required to avoid this pathophysiological process $[10,14,34]$. In this respect, the gut microbiota is quantitatively the most important source of microbial stimulation and may provide a primary signal for the maturation of a balanced postnatal innate [48] and adaptive immune system [10].

The gut microbiota differs in composition and diversity during the first months of life in children who later do or do not develop eczema [21, 22, 24, 48, 49] and asthma [50, 51], although no specific microbes with consistently harmful or allergy protective roles have yet been identified. Early establishment of a diverse gut microbiota, with repeated exposure to new bacterial antigens, may be more important than the distribution of specific microbial 
species in shaping a normal immune mucosal and systemic maturation [10]. In this regard, perinatal probiotic interventions have generally not affected gut microbiota diversity $[25,49$, 52], although the impact of prebiotic and combined probiotic and prebiotic (synbiotic) preventive interventions, which are more likely to affect diversity due to their growth promoting effects on a large variety of bacteria [6], has not been evaluated so far.

\section{Probiotics for treatment of allergic disease and asthma}

\section{Eczema}

Although the concept of probiotics is not novel [1], a new era of probiotic research targeting infants with food allergy and eczema was initiated in the 1990's. Early studies reported a preliminary benefit of feeding extensively hydrolysed whey formula with added Lactobacillus rhamnosus (L. rhamnosus) GG [53] and L. rhamnosus GG plus Bifidobacterium lactis (B. lactis) [54] on recovery of infant eczema and markers of intestinal inflammation. This was followed by clinical trials evaluating the effect of probiotics on established eczema in infants, children and adults. In the Cochrane review from 2008 [55], involving 781 infants and children (12 trials), the authors concluded that probiotics are not effective for eczema treatment. In a more recent meta-analysis [56], involving 1599 participants (infants, children and adults from 25 trials), the Scoring Atopic Dermatitis (SCORAD) values favoring probiotic treatment over the control were overall (mean $-4.51,95 \% \mathrm{Cl}-6.78$ to -2.24 ), in children 1 to 18 years old $(-5.74,95 \% \mathrm{Cl}-7.27$ to -4.20$)$, and in adults $(-8.26,95 \% \mathrm{Cl}-13.28$ to -3.25$)$. In infants $<1$ year old, there was no benefit of probiotics. This meta-analysis included studies using synbiotics, i.e. probiotics with added prebiotics, but found no evidence of a differential effect of probiotics and synbiotics. However, probiotic treatment with a combination of different bacterial species, or lactobacilli, was superior to treatment with bifidobacteria alone. The authors concluded that probiotics could be considered for eczema treatment in children and adults, despite heterogeneity of studies. As the doses used ranged from 0.3 to 20 billion colony-forming units, this could have contributed to the heterogeneity between studies. The various probiotic products used contained many different strains and the authors decided not 
to apply uniform dose criteria. Instead they underscored the need for comparative studies identifying the most effective strains, and optimization of dosing regimens in future studies, including a direct "head to head comparison study" to identify the most effective dose [56]. Since probiotic treatment studies have been small and heterogeneous, the generalizability of results has been questioned [57]. Based on the available evidence, expert bodies do not recommend probiotics for treatment of established eczema. An alternative future option might be topical bacteriotherapy as there is preliminary evidence of a benefit in the treatment of eczema. As this is outside the scope of the current review, we recommend a recent, comprehensive summary by Biedermann et al [58].

\section{Food allergy}

Apart from the early studies assessing the effects of probiotics in infants and children with eczema and food allergy, recent studies are scarcer. Hol and coworkers examined the effect of probiotics ( $L$. casei CRL431 plus $B$. lactis $\mathrm{Bb}-12$ ) added to extensively hydrolyzed caseinbased formula (EHCF) on tolerance acquisition in cow's milk allergic infants [59]. They randomly assigned infants to intake of EHCF with probiotics or EHCF alone. At 6 and 12 months of age, infants underwent a double-blind placebo-controlled food challenge to assess tolerance to cow's milk. The cumulative percentage of tolerance was high in both groups, $77 \%$ in the probiotic and $81 \%$ in the placebo group, with no statistically significant difference between the groups. Probiotic intake was accompanied by slightly lower frequencies of $\mathrm{CD}^{+}$ $\mathrm{T}$ cells and $\mathrm{CD} 3^{+} \mathrm{CD} 4^{+} \mathrm{T}$ helper cells at 12 months compared with EHCF without added probiotics, indicating immunemodulatory effects of this probiotic combination. Conversely, Berni Canani et al [60], reported a faster recovery when treating cow's milk allergic infants with EHCF with added L. rhamnosus GG for six months, compared with EHCF alone. Both of these randomized controlled trials (RCTs) included infants with $\lg \mathrm{E}$-mediated and non-lgEmediated cow's milk allergy, and in the latter, the benefit of EHCF with added LGG was more pronounced in non-IgE-mediated cow's milk allergy [60]. Non-lgE-mediated food allergies are complex disorders and little is yet known about their pathophysiology [61]. Consequently, 
future studies are needed to examine the mechanistic effects of probiotics in both $\lg \mathrm{E}$ mediated and non-IgE-mediated cow's milk allergy.

Studies assessing probiotics for treatment of food allergy beyond cow's milk allergy are even scarcer. Notably, in a recent study by Tang and coworkers [62], a combination of peanut and probiotic (L. rhamnosus) oral immunotherapy (OIT) induced desensitization in $89.7 \%$ of the subjects compared with $7.1 \%$ in the placebo arm (who received a similar product with neither peanut nor probiotic) $(p<0.001)$. Although promising, a three-arm design is necessary to disentangle if the benefit of the combined peanut and probiotic therapy is superior to peanut OIT alone.

\section{Allergic rhinitis and asthma}

Probiotics have been examined in the treatment of allergic rhinitis in RCTs and randomized crossover studies. In a recent systematic review and meta-analysis 1919 patients (23 trials) were included [63]. A variety of outcome measures were used in these trials, e.g. Rhinits Quality of Life Scores and Rhinitis Total Symptom Scores, but also total and allergen-specific IgE concentrations. Of the 23 studies included, 17 reported a clinical benefit of probiotics in at least one outcome measure. Meta-analysis showed that the overall quality of life scores were improved in those treated with probiotics. No benefit of probiotic treatment was shown for the other outcomes. The authors identified that studies were heterogeneous in terms of the probiotic(s) used, study populations and outcomes measures. They concluded that probiotics may be beneficial for improving quality of life and symptoms in patients with allergic rhinitis, but stressed the need for well-designed studies before general recommendations can be given [63]. Studies have also assessed the effect of probiotics for asthma treatment and in a meta-analysis including four RCTs, there was no benefit [64]. Collectively, the available evidence does not support the use of probiotics for treatment of established allergic diseases or asthma. 


\section{Probiotics for primary prevention of allergic diseases and asthma}

\section{Eczema}

As shown in Table 1, probiotics have been examined as a preventive measure in several RCTs [36-41, 65-74]. All of these studies assessed the preventive effects on eczema in infancy and early childhood. Follow-up data on eczema and respiratory allergic diseases at 4 years of age $[75,76]$ and in children $\geq 5$ years have been reported [77-85] (Table 1), however, several of the studies are still ongoing and follow-up data are not yet available. Probiotics have been administered in the form of drops, in sachets and in infant foods. Most studies have used a combined perinatal administration, with the probiotic given to the mother in pregnancy and then postnatally either to the mother while breast-feeding or to the infant directly (Table 1). Consistent with previous meta-analyses, two very recent meta-analyses concluded that there is a benefit of probiotics for primary prevention of eczema [86, 87]. Cuello-Garica et al concluded that probiotic use by pregnant or breast-feeding mothers and/or when given to infants reduced the risk of eczema in infants albeit the certainty of evidence is low due to risk of bias, inconsistency and imprecision of estimated effect [86]. Although the evidence for a combined perinatal intervention is stronger, studies initiating the probiotic intervention postnatally are scarce. It also remains unanswered when in the gestation period the intervention should be initiated, and for how long is should continue in the postnatal period. The authors further stressed the need for well-designed trials and suggested that a direct comparison of different probiotics could be useful [86].

\section{Food allergy and respiratory allergic disease}

The benefits for probiotics in the prevention of other allergic conditions remain low $[87,88]$. The Prevention Taskforce for the European Academy of Allergy and Clinical Immunology's (EAACI) Guidelines for Food allergy and Anaphylaxis has concluded that current evidence is lacking to support their administration to prevent food allergy [89] and in a recent metaanalysis there was no evidence to support a benefit of perinatal probiotic treatment on doctor diagnosed asthma or childhood wheeze [90]. On the other hand, Cuello-Garcia et al 
concluded that even though the currently available evidence does not support that probiotics reduce the risk of other allergic manifestations than eczema, the evidence does not exclude such as possibility either [86].

\section{Tailoring probiotic intervention for specific groups}

There are also certain high-risk groups that may benefit from probiotic supplementation. In the largest RCT for allergy prevention, supplementation of pregnant women (whose fetuses were at high family risk for atopy) with a lactobacillus and bifidobacterial combination and of their newborns with the same probiotics plus a prebiotic for 6 months (Table 1), Kuitunen et al found less IgE-associated eczema and food sensitization at age 2 but not at age 5 [39, 81]. However, Cesarean delivered children $(n=149)$ who were treated with probiotics had significantly fewer IgE-associated allergic diseases at age 5, particularly eczema (15.7\% vs $30.4 \%$; Odds Ratio, $0.43 ; 95 \% \mathrm{Cl}, 0.19-0.95$ ) and food sensitization (10.0\% vs $25.3 \%$; Odds Ratio, $0.33 ; 95 \% \mathrm{Cl}, 0.12$ - 0.85) compared with Cesarean delivered children who received placebo. These associations were not adjusted for any factors such as extent of breastfeeding, siblingship or pets in the home. The Cesarean section rate was $16.7 \%$ in this study. No results were reported for vaginally delivered children.

In a recent publication from the population-based MoBa (Norwegian Mother and Child

Cohort Study) observational cohort study, the effectiveness of lactobacillus-bifidobacterial milk and yogurt (Biola, Cultura) product consumption was evaluated in 35,000 vaginally delivered infants in Norway [91]. Questionnaire-reported maternal milk and yougurt Consumption during pregnancy at 18,22 and 30 weeks of gestation and postnatally at 6,18 , and 36 months, in conjunction with the administration of the same probiotics to infants between 6-18 months of age, significantly reduced the likelihood of eczema at 6 months (adjusted Odds Ratio, 0.94; 95\%Cl: 0.89-0.99) and rhinoconjunctivitis (adjusted Odds Ratio, $0.87 ; 95 \% \mathrm{Cl}: 0.78-0.98)$ at $18-36$ months. These associations were independent of breastfeeding status; maternal history of allergy, age, smoking during pregnancy, pre-pregnancy 
BMI, dietary fiber intake and energy intake; parity; infant's sex and mode of delivery. A reduction in allergic disease outcomes with probiotic treatment was not observed in 5,557 Cesarean-delivered infants, comprising $15 \%$ of the cohort. Even though this is still a large sample size, it cannot be precluded that loss of statistical power contributed to this finding. Also inconsistent with the Kuitunen et al high risk study [81] were results related to family history of atopy. One quarter of women had self-reported atopy in the MoBa cohort [91]. No reduction in atopic disease after probiotic treatment was seen in their infants, in contrast to statistical significance achieved among infants with a negative family history.

Several cohort studies have confirmed that relative to vaginal delivery, Cesarean section delays post birth increases in the abundance and diversity of bifidobacteria, and reduces maternal-infant sharing of bifidobacterial species [18, 19, 24], a phenomenon which appears to be remedied by infant probiotic treatment in the Kuitunen study [81]. Indeed, bifidobacterial diversity was also observed to be lower among cesarean-delivered infants who developed eczema in the Hong et al study, yet it did not differ between vaginally born infants who did and did not develop eczema [24]. The nature of gut dysbiosis that predicts atopic disease remains to be determined. In the interim, it is conceivable that probiotic-induced alterations to infant gut microbial composition, directly and indirectly through breast milk [92] enhance colonization resistance to microbes such as $C$. difficile, and this change is more beneficial to the infant after Cesarean delivery. Colonization of the infant gut with $C$. difficile is becoming increasingly more prevalent than it was in the 1980s [26], especially following Cesarean delivery [16]. Associations between Cesarean induced dysbiosis of the gut and atopic disease have been found to be mediated by $C$. difficile colonization [21, 22].

As nicely shown by Mastromarino et al [23], inconsistencies in the effectiveness of maternal probiotic treatment in preventing allergic disease in offspring may be attributed to birth method since Cesarean delivery may alter the systemic effects of probiotics in the mother. In their study of probiotic treatment between 36 weeks of gestation and 1 month after birth, 
elevations in colostrum and mature breast milk of lactobacilli and bifidobacteria were reported after the probiotic treatment of women who delivered vaginally $(n=46)$ but not among women who had delivered by cesarean $(n=20)$. What then, could explain conflicting results in probiotic effectiveness within cesarean-delivered infants? In both the Kuitunen and Bertelsen studies $[81,91]$ mothers and infants received probiotic formulations prenatally and following delivery for approximately 6 months. Differences in probiotic dose, duration or species strain, co-administration of prebiotics (Kuitunen study), lack of randomization and blinding (Bertelsen study), age and method of atopic disease evaluation are candidate explanations, as are sample size, family history of atopy, duration of breastfeeding, extent of antibiotic use, and other confounding factors which can bias observational cohorts and randomized controlled trials. But type of Cesarean section also has a potential role to play. Newborns are not exposed to maternal vaginal microbes such as lactobacilli, during elective Cesarean but this exposure may occur during emergency Cesarean after attempted vaginal birth. Hence, the early gut microbiota profiles of infants delivered by emergency Cesarean are found to differ from those following elective Cesarean, independent of breastfeeding status [17]. In neither the Kuitunen nor Bertelsen studies were separate results presented for elective versus emergency cesarean or the percentage contribution for each type reported within the cesarean groups $[81,91]$. Further in Norway, women undergoing elective cesarean delivery were not pre-treated with antibiotics at the time of the MOBA cohort study [93]. Data from the clinical follow-up at school age of the Kuitunen study [81], will provide more insight into the effects of perinatal probiotic treatment but also on long-term outcomes. Ultimately, new intervention studies designed to evaluate if stronger long term effects of probiotic supplementation are observed in children delivered by cesarean section than in vaginally delivered children would further clarify these issues.

\section{Current recommendations}

In 2015 the World Allergy Organization applied the GRADE (Grading of Recommendations, Assessment, Development and Evaluation) approach to the evidence in this field [94], which 
balances desirable and undesirable consequences, the quality of the evidence, and consumer preferences and values [95]. Consistent with other meta-analyses [86, 87] and considering all critical outcomes they concluded that there is a net benefit from using probiotics (in pregnancy, lactation and in infancy) resulting from the prevention of eczema when there is considered to be a high-risk of allergy (based on a history of allergy in the immediate family). Based on this the WAO guideline panel suggested using probiotics in pregnant and lactating women, and in infants when there is high risk of allergy in the children. This recommendation places a relatively high value on prevention of eczema in children, and a relatively lower value on avoiding possible adverse effects [94]. The panel also recognized that the recommendation was supported by very low quality evidence, and there was a lack of evidence that probiotics prevented any other allergy. Although the strain of probiotic is likely to be important, there is insufficient evidence to recommend specific strains at specific times, or for specific durations. For this reason, it has been difficult to translate the WAO recommendations into practice guidelines [96, 97]. In our own attempt to do this, we highlighted to consumers and practitioners that 'the great heterogeneity of the studies makes it difficult to advise on specifics regarding therapy (eg, strains, dose, timing, and duration)' [96]. Based on the paucity of evidence to address these questions, we were unable to recommend giving probiotics during pregnancy, lactation and infancy for the prevention of eczema. However, we also recognize that the data suggest that there is a modest preventive effect of probiotics on the development of eczema, but not other atopic diseases, in at-risk infants (defined as presence of a biologic parent or sibling with asthma, allergic rhinitis, eczema, or food allergy)' [96]. Based on these potential benefits, in our experience some parents are still interested in using probiotics, particularly as though risk of adverse effects is low. In that situation scenario, we emphasize that documented benefits appear limited to eczema, that the evidence is weak, and that any risk reduction is likely to be small. 
So what do we say in our own personal clinical practice when confronted with this question? Our approach is to emphasize that currently the best way to improve our healthy gut microbiome is a healthy balanced diet - rich in fiber and fresh fruit and vegetables particularly in pregnancy, lactation and infancy, but ideally at every stage of life. This is likely to have many other benefits for the mother, and lasting effects on the child, including healthy dietary patterns and future taste preferences. It is currently difficult to recommend specific commercial products for 'gut health', and a whole food approach is likely to have more general health and societal benefits. For respiratory outcomes, we also support the conclusions emanating from the 2013 National Heart Lung and Blood Institute (NHLBI) workshop on the primary prevention of chronic lung diseases, suggesting that potential universal lung health strategies to prevent chronic lung disease could include prevention of preterm delivery, reduction of exposure of the fetus and young infant to environmental pollutants and tobacco smoke, reduction of psychosocial stress and prevention of maternal and child obesity [98].

\section{Conclusion}

With increasing evidence that our modern environment has detrimental effects on the human gut microbiota and its diversity, there has been intense interest in the promotion and restoration of gut microbial composition using probiotic interventions. While meta-analyses have shown a moderate effect of probiotics for eczema prevention, there is less evidence of an effect for the treatment and prevention of other allergic manifestations. Because of very low quality evidence and heterogeneity between studies, specific advice on probiotic regimens cannot yet be given for any allergic condition. Looking back, we can see that the still rudimentary understanding of the complexity of gut microbiota- host interactions has made it difficult to design the most effective interventions. Moving forward, we see the need for multidisciplinary collaborations in large networks $[6,10]$. We anticipate that powerful sequencing techniques and bioinformatics tools will aid in deciphering the mechanistic effects of probiotics, however, to be able to deliver specific clinical guidelines, we need 
adequately powered and prospective clinical trials, using uniform strategies and clinical outcome measures [6, 10, 96-97].

\section{Expert commentary}

Probiotics are "live micro-organisms, which when administered in adequate amounts, confer a health benefit on the host [99]. Typically, strains of lactobacilli and bifidobacteria, or their combinations, have been evaluated for the treatment or prevention of manifestations of allergic disease in clinical trials. Meta-analyses show a benefit of probiotics for eczema prevention $[86,87]$, but there is limited evidence of an effect in the treatment and prevention of other allergic manifestations. In 2015 the World Allergy Organization (WAO) launched guidelines on the use of probiotics as a preventive strategy to reduce allergic diseases [94]. Considering all critical outcomes, they concluded that there is a net benefit from using probiotics (in pregnancy, lactation and in infancy) resulting from the prevention of eczema when there is considered to be a high-risk of allergy (a history of allergy in the immediate family). The WAO guideline panel thus suggested using probiotics in pregnant and lactating women, and in infants when there is high risk of allergy in the children. However, the panel stressed that the recommendation was supported by very low quality evidence, and that there was a lack of evidence that probiotics prevented any other allergy. Although the strain of probiotic is likely to be important, there is insufficient evidence to recommend specific strains at specific times, or for specific durations. For this reason, it has been difficult to translate the WAO recommendations into practice guidelines [96, 97]. Consequently, specific recommendations on probiotic regimens cannot yet be given.

\section{Five-year view}

Probiotics remain a promising strategy to influence early gut colonization, gut integrity and immune response patterns in allergic disease. We anticipate metagenomic, metaproteomic and metabolomic studies examining the impact of probiotic supplementation to shed light on the mechanistic and functional aspects of probiotic interventions. As long-term follow data on 
already initiated cohorts using probiotics for the primary prevention of allergic disease are limited, we await the results of currently ongoing clinical trials with interest. The use of synbiotics is another emerging option, which is anticipated to have more global effects on intestinal colonization. The results of ongoing clinical trials examining the effects of synbiotics in the treatment and prevention of allergic disease will provide more insight.

\section{Key issues}

- A dysbiotic gut microbiota is associated with increased risk of developing allergic diseases and asthma in cross-sectional and observational studies, but a clear causeeffect relationship has not been demonstrated.

- Animal models provide evidence that intestinal colonization is key to normal development of immune functions and regulation.

- The WHO/FAO definition of probiotics is "Live micro-organisms, which when administered in adequate amounts, confer a health benefit on the host" [1].

- Probiotics have immunemodulating effects and these effects are considered strainspecific.

- The most commonly used probiotics for prevention and treatment of allergic diseases and asthma are strains of lactobacilli and bifidobacteria, and their combinations.

- Meta-analyses have shown a moderate benefit of probiotics for eczema prevention, but there is little evidence of a treatment or preventive effect for other allergic manifestations.

- Very low quality evidence and heterogeneity between studies have precluded translation of the results from clinical trials and meta-analyses into clear clinical recommendations.

- There is still need for well-designed, prospective clinical trials both in the treatment and prevention of allergic diseases and asthma. 


\section{Financial \& competing interests disclosure}

C West has received research support from Arla Foods AB, Danone Nutricia; has received speaker's honoraria from Nestle Nutrition, Arla Foods and HiPP; has received royalties from UPToDate; and has received travel support from Nestle Nutrition. M Jenmalm has received lecture fees from BioGaia $A B$, Sweden. S Prescott is on the advisory board and has received speaker's honoraria from Nestle Nutrition Institute and Danone Nutricia; has received research support from Nestle Nutrition Institute; has received lecture fees from Nestle Nutrition Institute and Danone Nutricia; has received travel support and speaker's honorarium from ALK Abello; and has received royalties from UpToDate. The authors have no other relevant affiliations or financial involvement with any organization or entity with a financial interest in or financial conflict with the subject matter or materials discussed in the manuscript apart from those disclosed. 


\section{References}

\section{Reference annotations}

* Of interest

** Of considerable interest

1. Podolsky SH. Metchnikoff and the microbiome. Lancet. 2012;24;380:1810-1.

2. Logan AC, Katzman MA, Balanza-Martinez V. Natural environments, ancestral diets, and microbial ecology: is there a modern "paleo-deficit disorder"? Part II. JPhysiol Anthropol. 2015;34:9.

3. Dubos R, Schaedler RW. Some biological effects of the digestive flora. Am J Med Sci. 1962;244:265-71.

4. Prescott SL. Early-life environmental determinants of allergic diseases and the wider pandemic of inflammatory noncommunicable diseases. J Allergy Clin Immunol. 2013;131:2330.

5. Blaser M. Antibiotic overuse: Stop the killing of beneficial bacteria. Nature. 2011;476:393-4.

6. West $\mathrm{CE}$, Renz $\mathrm{H}$, Jenmalm MC, et al. The gut microbiota and inflammatory noncommunicable diseases: Associations and potentials for gut microbiota therapies. J Allergy Clin Immunol. 2015;135:3-13.

7. Thorburn AN, McKenzie $\mathrm{Cl}$, Shen S, et al. Evidence that asthma is a developmental origin disease influenced by maternal diet and bacterial metabolites. Nature communications. $2015 ; 6: 7320$.

** In this experimental model, feeding mice a high-fiber diet induced a distinctive gut microbiota, with higher levels of the short-chain fatty acid acetate. High-fiber or acetatefeeding led to marked suppression of allergic airways disease by enhanced T-regulatory cell numbers and function. In addition, high-fiber/acetate feeding of pregnant mice suppressed the expression of certain genes in the mouse fetal lung linked to both human asthma and 
experimental allergic airways disease. The authors concluded that a diet influencing the gut microbiota may represent a strategy to prevent asthma, also in pregnancy.

8. Belkaid $\mathrm{Y}$, Hand TW. Role of the microbiota in immunity and inflammation. Cell. 2014;157:121-41.

9. Jenmalm MC. Childhood immune maturation and allergy development: regulation by maternal immunity and microbial exposure. Am J Reprod Immunol. 2011;66 Suppl 1:75-80.

10. West CE, Jenmalm MC, Prescott SL. The gut microbiota and its role in the development of allergic disease: a wider perspective. Clin Exp Allergy. 2015;45:43-53,

11. Aagaard K, Ma J, Antony KM, et al. The placenta harbors a unique microbiome. Sci Transl Med. 2014;6:237ra65.

** This study showed that low amounts of DNA from bacterial phyla are also found in the placenta of a healthy pregnancy, and that these phyla are resembling those in the mouth and not the phyla present in closer anatomic regions e.g. the vagina, gut or on the skin.

12. Funkhouser LJ, Bordenstein SR. Mom knows best: the universality of maternal microbial transmission. PLoS biology. 2013;11:e1001631.

13. Stout MJ, Conlon B, Landeau M, et al. Identification of intracellular bacteria in the basal plate of the human placenta in term and preterm gestations. Am J Obstet Gynecol. 2013;208:226 e1-7.

14. Abrahamsson TR, Wu RY, Jenmalm MC. Gut microbiota and allergy: the importance of the pregnancy period. Pediatr Res. 2015;77:214-9.

15. Jimenez E, Fernandez L, Marin ML, et al. Isolation of commensal bacteria from umbilical cord blood of healthy neonates born by cesarean section. Curr Microbiol. 2005;51:270-4.

16. Azad MB, Konya $\mathrm{T}$, Maughan $\mathrm{H}$, et al. Gut microbiota of healthy Canadian infants: profiles by mode of delivery and infant diet at 4 months. CMAJ. 2013;185:385-94.

17. Azad MB, Konya T, Persaud RR, et al. Impact of maternal intrapartum antibiotics, method of birth and breastfeeding on gut microbiota during the first year of life: a prospective cohort study. BJOG. 2015 Sep 28, epub ahead of print. 
* This paper documented altered gut microbial composition in full-term infants following intrapartum antibiotic prophylaxis, especially with emergency cesarean delivery. This dysbiosis persisted at 1 year of age only among infants who were not exclusively breastfed at age 3 months.

18. Bäckhed F, Roswall J, Peng Y, et al. Dynamics and Stabilization of the Human Gut Microbiome during the First Year of Life. Cell Host Microbe. 2015;17:690-703.

${ }^{* *}$ This study assessed the gut microbiomes of mothers and their infants in their first year of life, showing that weaning induces maturation of the gut microbiota. Maturation of the infant gut microbiome was accompanied by shifts in nutrient and xenobiotic metabolism.

19. Dogra S, Sakwinska O, Soh SE, et al. Dynamics of infant gut microbiota are influenced by delivery mode and gestational duration and are associated with subsequent adiposity. mBio. 2015;6(1).

20. Jakobsson HE, Abrahamsson TR, Jenmalm MC, et al. Decreased gut microbiota diversity, delayed Bacteroidetes colonisation and reduced Th1 responses in infants delivered by caesarean section. Gut. 2014;63:559-66.

*This study showed that children born through Cesarean section had lower total microbiota diversity in infancy than vaginally delivered children. Persistent changes in the gut microbiota were demonstrated up to two years of age, particularly a decreased diversity of the Bacteroidetes phylum among Cesarean delivered children. Cesarean delivery was associated with a delayed maturation of Th1-associated immunity.

21. Penders J, Gerhold K, Stobberingh EE, et al. Establishment of the intestinal microbiota and its role for atopic dermatitis in early childhood. J Allergy Clin Immunol. 2013;132:601-7 e8.

22. van Nimwegen FA, Penders J, Stobberingh EE, et al. Mode and place of delivery, gastrointestinal microbiota, and their influence on asthma and atopy. J Allergy Clin Immunol. 2011;128:948-55 e1-3.

23. Mastromarino P, Capobianco D, Miccheli A, et al. Administration of a multistrain probiotic product (VSL\#3) to women in the perinatal period differentially affects breast milk 
beneficial microbiota in relation to mode of delivery. Pharmacol Res. 2015;95-96:63-70.

*This is the first paper to show an alteration in breast milk lactobacilli and bifidobacteria with maternal probiotic treament seen after vaginal but not cesarean delivery.

24. Hong PY, Lee BW, Aw M, et al. Comparative analysis of fecal microbiota in infants with and without eczema. PLoS One. 2010;5:e9964.

25. Rutten NB, Gorissen DM, Eck A, et al. Long Term Development of Gut Microbiota Composition in Atopic Children: Impact of Probiotics. PLoS One. 2015;10:e0137681.

*The gut microbiota modulating effects of supplementation with placebo or Lactococcus lactis, Bifidobacterium lactis W52 and B. bifidum W23 $\left(1 \times 10^{9}\right.$ CFU each daily) six weeks before delivery and then directly to infants for 12 months were evaluated up to six years of age in this study. The supplemented probiotic strains were detected in fecal samples during the intervention, but did not clearly affect gut microbiota composition and diversity. Interestingly, gut microbiota development continued between two and six years, then approaching a more adult-like composition.

26. Adlerberth I, Wold AE. Establishment of the gut microbiota in Western infants. Acta Paediatr. 2009;98:229-38.

27. Cahenzli J, Koller Y, Wyss M, et al. Intestinal microbial diversity during early-life colonization shapes long-term IgE levels. Cell Host Microbe. 2013;14:559-70.

28. Sudo N, Sawamura S, Tanaka K, et al. The requirement of intestinal bacterial flora for the development of an IgE production system fully susceptible to oral tolerance induction. $J$ Immunol. 1997; 159:1739-45.

29. Olszak T, An D, Zeissig S, et al. Microbial exposure during early life has persistent effects on natural killer T cell function. Science. 2012;336:489-93.

30. An D, Oh SF, Olszak T, et al. Sphingolipids from a symbiotic microbe regulate homeostasis of host intestinal natural killer T cells. Cell. 2014;156:123-33.

** In this murine model, inhibitory sphingolipids from Bacteroides fragilis (B. fragilis) modified the homeostasis of host iNKT cells, effectively limiting iNKT cell proliferation during neonatal development and restricting total colonic iNKT cell numbers into adulthood. B. fragilis 
colonized hosts were protected against experimental iNKT cell-mediated, oxazolone-induced colitis. When germ free pregnant dams were cohoused with $B$. fragilis monocolonized mice before delivery, the offspring's colonic iNKT cell numbers were not normalized to the level observed when germ free dams were mated with $B$. fragilis monocolonized mice, although at time of delivery, the mother was heavily colonized with B. fragilis bacteria. Thus, presence of B. fragilis during a prolonged prenatal period seemed to be required for achieving iNKT cell homeostasis.

31. El Aidy S, Hooiveld G, Tremaroli V, et al. The gut microbiota and mucosal homeostasis: colonized at birth or at adulthood, does it matter? Gut Microbes. 2013;4:11824.

32. Yamamoto $\mathrm{M}$, Yamaguchi $\mathrm{R}$, Munakata $\mathrm{K}$, et al. A microarray analysis of gnotobiotic mice indicating that microbial exposure during the neonatal period plays an essential role in immune system development. BMC genomics. 2012:13:335.

33. Hansen $\mathrm{CH}$, Nielsen DS, Kverka M, et al Patterns of early gut colonization shape future immune responses of the host. PLoS One. 2012;7:e34043.

34. Jenmalm MC, Duchen K. Timing of allergy-preventive and immunomodulatory dietary interventions - are prenatal, perinatal or postnatal strategies optimal? Clin Exp Allergy. 2013;43:273-8.

35. von Mutius E, Vercelli D. Farm living: effects on childhood asthma and allergy. Nat Rev Immunol. 2010;10:861-8.

36. Abrahamsson TR, Jakobsson T, Böttcher MF, et al. Probiotics in prevention of IgEassociated eczema: a double-blind, randomized, placebo-controlled trial. J Allergy Clin Immunol. 2007;119:1174-80.

37. Dotterud CK, Storro O, Johnsen R, et al. Probiotics in pregnant women to prevent allergic disease: a randomized, double-blind trial. Br J Dermatol. 2010;163:616-23.

38. Kalliomäki M, Salminen $\mathrm{S}$, Arvilommi H, et al. Probiotics in primary prevention of atopic disease: a randomised placebo-controlled trial. Lancet. 2001;357:1076-9.

39. Kukkonen K, Savilahti E, Haahtela T, et al. Probiotics and prebiotic galacto- 
oligosaccharides in the prevention of allergic diseases: a randomized, double-blind, placebocontrolled trial. J Allergy Clin Immunol. 2007;119:192-8.

40. Rautava S, Kainonen E, Salminen S, et al. Maternal probiotic supplementation during pregnancy and breast-feeding reduces the risk of eczema in the infant. J Allergy Clin Immunol. 2012;130:1355-60.

41. Wickens K, Black PN, Stanley TV, et al. A differential effect of 2 probiotics in the prevention of eczema and atopy: a double-blind, randomized, placebo-controlled trial. J Allergy Clin Immunol. 2008;122:788-94.

42. Abelius MS, Lempinen E, Lindblad K, et al. Th2-like chemokine levels are increased in allergic children and influenced by maternal immunity during pregnancy. Pediatr Allergy Immunol. 2014;25:387-93.

43. Forsberg A, Abrahamsson TR, Björkstén B, et al. Pre- and post-natal Lactobacillus reuteri supplementation decreases allergen responsiveness in infancy. Clin Exp Allergy. 2013;43:434-42.

44. Forsberg A, Abrahamsson TR, Björkstén B, et al. Pre- and postnatal administration of Lactobacillus reuteri decreases TLR2 responses in infants. Clin Transl Allergy. 2014;4:21.

45. Abrahamsson TR, Sandberg Abelius M, Forsberg A, et al. A Th1/Th2-associated chemokine imbalance during infancy in children developing eczema, wheeze and sensitization. Clin Exp Allergy. 2011;41:1729-39.

46. Abelius MS, Ernerudh J, Berg G, et al. High cord blood levels of the T-helper 2associated chemokines CCL17 and CCL22 precede allergy development during the first 6 years of life. Pediatr Res. 2011;70:495-500.

47. Fagerås $\mathrm{M}$, Tomicic $\mathrm{S}$, Voor $\mathrm{T}$, et al. Slow salivary secretory IgA maturation may relate to low microbial pressure and allergic symptoms in sensitized children. Pediatr Res. 2011;70:572-7.

48. West $\mathrm{CE}$, Rydén $\mathrm{P}$, Lundin $\mathrm{D}$, et al. Gut microbiome and innate immune response patterns in IgE-associated eczema. Clin Exp Allergy. 2015;45:1419-29.

*In this study, reduced relative abundance of tolerance associated gut bacteria, e.g. 
Proteobacteria and Ruminoccoccaceae, was seen in infants developing lgE-associated eczema compared with infants that remained non-allergic. The reduction of these gut bacteria was associated with exaggerated innate immune responses and higher production of inflammatory biomarkers.

49. Abrahamsson TR, Jakobsson HE, Andersson AF, et al. Low diversity of the gut microbiota in infants with atopic eczema. J Allergy Clin Immunol. 2012;129:434-40, 40 e1-2.

50. Abrahamsson TR, Jakobsson HE, Andersson AF, et al. Low gut microbiota diversity in early infancy precedes asthma at school age. Clin Exp Allergy. 2014;44:842-50.

*In this study, children with asthma at school age had a lower diversity of the total microbiota at one week and one month of age compared with non-asthmatic children. A similar association was not found for allergic rhinoconjunctivitis, although both these findings should be confirmed in larger studies. The authors speculated that a less diverse microbial stimulation could have resulted in a reduced mucosal barrier function, leading to increased airway viral infection susceptibility, amplification of Th2 responses and subsequent asthma development.

51. Arrieta MC, Stiemsma LT, Dimitriu PA, et al. Early infancy microbial and metabolic alterations affect risk of childhood asthma. Sci Transl Med. 2015;7:307ra152.

** In this study, the gut microbiome of 319 infants was assessed. Infants at risk of asthma demonstrated transient gut microbial dysbiosis in the first 100 days of life with lower relative abundance of Lachnospira, Veillonella, Faecalibacterium and Rothia. This occured in conjunction with reduced acetate levels in stool and dysregulation of enterohepatic metabolites. When germ-free mice were inoculated with these four taxa, reduced airway inflammation in their adult offspring was seen, suggesting a role of these taxa in preventing asthma. Neutrophilic but not eosinophilic infiltration was attenuated by the inoculation, possibly questioning the relevance for human pediatric asthma, which is typically eosinophilia-dominated.

52. Dotterud CK, Avershina E, Sekelja M, et al. Does Maternal Perinatal Probiotic Supplementation Alter the Intestinal Microbiota of Mother and Child? A Randomized 
Controlled Trial. J Pediatr Gastroenterol Nutr. 2015;61:200-7.

*Intake of a probiotic combination in pregnancy and during breastfeeding reduced the incidence of eczema in childhood, and in this study it was shown that only one of the administered strains, L. rhamnosus GG, increased in the infant's stool during the intervention. This suggests that specific probiotic strains are more apt to transfer from mother to child.

53. Majamaa H, Isolauri E. Probiotics: a novel approach in the management of food allergy. J Allergy Clin Immunol. 1997;99:179-85.

54. Isolauri E, Arvola T, Sutas $\mathrm{Y}$, et al. Probiotics in the management of atopic eczema. Clin Exp Allergy. 2000;30:1604-10.

55. Boyle RJ, Bath-Hextall FJ, Leonardi-Bee J, et al. Probiotics for treating eczema. Cochrane Database Syst Rev. 2008 (4):CD006135.

56. Kim SO, Ah YM, Yu YM, et al. Effects of probiotics for the treatment of atopic dermatitis: a meta-analysis of randomized controlled trials. Ann Allergy Asthma Immunol. 2014;113:217-26.

57. Baquerizo Nole KL, Yim E, Keri JE. Probiotics and prebiotics in dermatology. J Am Acad Dermatol. 2014;71:814-21.

58. Biedermann T, Skabytska Y, Kaesler S, et al. Regulation of T Cell Immunity in Atopic Dermatitis by Microbes: The Yin and Yang of Cutaneous Inflammation. Front Immunol. $2015 ; 6: 353$

59. Hol J, van Leer EH, Elink Schuurman BE, et al. The acquisition of tolerance toward cow's milk through probiotic supplementation: a randomized, controlled trial. J Allergy Clin Immunol. 2008;12:1448-54.

60. Berni Canani R, Nocerino R, Terrin G, et al. Effect of Lactobacillus GG on tolerance acquisition in infants with cow's milk allergy: a randomized trial. J Allergy Clin Immunol. 2012;129:580-2, 2 e1-5.

61. Nowak-Wegrzyn A, Katz Y, Mehr SS, et al. Non-lgE-mediated gastrointestinal food allergy. J Allergy Clin Immunol. 2015;135:1114-24. 
62. Tang ML, Ponsonby AL, Orsini F, et al. Administration of a probiotic with peanut oral immunotherapy: A randomized trial. J Allergy Clin Immunol. 2015;135:737-44 e8.

${ }^{*}$ Compared with placebo, the combination of peanut oral immunotherapy and intake of a probiotic L. rhamnosus strain induced desensitization at a much higher rate. This interesting observation should be evaluated using a three-arm design to examine if the benefit of the combined peanut and probiotic therapy is superior to peanut oral immunotherapy alone.

63. Zajac AE, Adams AS, Turner JH. A systematic review and meta-analysis of probiotics for the treatment of allergic rhinitis. Int Forum Allergy Rhinol. 2015;5:524-32

64. Vliagoftis H, Kouranos VD, Betsi GI, et al. Probiotics for the treatment of allergic rhinitis and asthma: systematic review of randomized controlled trials. Ann Allergy Asthma Immunol. 2008;101:570-9.

65. Soh SE, Aw M, Gerez I, et al. Probiotic supplementation in the first 6 months of life in at risk Asian infants--effects on eczema and atopic sensitization at the age of 1 year. Clin Exp Allergy. 2009;39:571-8.

66. Taylor AL, Dunstan JA, Prescott SL. Probiotic supplementation for the first 6 months of life fails to reduce the risk of atopic dermatitis and increases the risk of allergen sensitization in high-risk children: a randomized controlled trial. J Allergy Clin Immunol. 2007;119:184-91.

67. Allen SJ, Jordan S, Storey $\mathrm{M}$, et al. Probiotics in the prevention of eczema: a randomised controlled trial. Arch Dis Child. 2014;99:1014-9.

68. Boyle RJ, Ismail IH, Kivivuori S, et al. Lactobacillus GG treatment during pregnancy for the prevention of eczema: a randomized controlled trial. Allergy. 2011;66:509-16.

69. Kim JY, Kwon JH, Ahn SH, et al. Effect of probiotic mix (Bifidobacterium bifidum, Bifidobacterium lactis, Lactobacillus acidophilus) in the primary prevention of eczema: a double-blind, randomized, placebo-controlled trial. Pediatr Allergy Immunol. 2010;21:e38693.

70. Kopp MV, Hennemuth I, Heinzmann A, et al. Randomized, double-blind, placebocontrolled trial of probiotics for primary prevention: no clinical effects of Lactobacillus GG supplementation. Pediatrics. 2008;121:e850-6. 
71. Niers L, Martin R, Rijkers G, et al. The effects of selected probiotic strains on the development of eczema (the PandA study). Allergy. 2009;64:1349-58.

72. Ou CY, Kuo HC, Wang L, et al. Prenatal and postnatal probiotics reduces maternal but not childhood allergic diseases: a randomized, double-blind, placebo-controlled trial. Clin Exp Allergy. 2012;42:1386-96.

73. West $\mathrm{CE}$, Hammarström ML, Hernell O. Probiotics during weaning reduce the incidence of eczema. Pediatr Allergy Immunol. 2009;20:430-7.

74. Huurre A, Laitinen K, Rautava S, et al. Impact of maternal atopy and probiotic supplementation during pregnancy on infant sensitization: a double-blind placebo-controlled study. Clin Exp Allergy. 2008;38:1342-8.

75. Kalliomäki M, Salminen S, Poussa T, et al. Probiotics and prevention of atopic disease: 4-year follow-up of a randomised placebo-controlled trial. Lancet, 2003;361:1869-71.

76. Wickens K, Black P, Stanley TV, et al. A protective effect of Lactobacillus rhamnosus HN001 against eczema in the first 2 years of life persists to age 4 years. Clin Exp Allergy. 2012;42:1071-9.

77. Abrahamsson TR, Jakobsson T, Björkstén B, et al. No effect of probiotics on respiratory allergies: a seven-year follow-up of a randomized controlled trial in infancy. Pediatr Allergy Immunol 2013;24:556-61.

78. Gorissen DM, Rutten NB, Oostermeijer CM, et al. Preventive effects of selected probiotic strains on the development of asthma and allergic rhinitis in childhood. The Panda study. Clin Exp Allergy. 2014;44:1431-3.

79. Jensen MP, Meldrum S, Taylor AL, et al. Early probiotic supplementation for allergy prevention: long-term outcomes. J Allergy Clin Immunol. 2012;130:1209-11 e5.

80. Kalliomäki M, Salminen S, Poussa T, et al. Probiotics during the first 7 years of life: a cumulative risk reduction of eczema in a randomized, placebo-controlled trial. J Allergy Clin Immunol. 2007;119:1019-21.

81. Kuitunen M, Kukkonen $\mathrm{K}$, Juntunen-Backman $\mathrm{K}$, et al. Probiotics prevent IgEassociated allergy until age 5 years in cesarean-delivered children but not in the total cohort. 
J Allergy Clin Immunol. 2009;123:335-41.

82. Loo EX, Llanora GV, Lu Q, et al. Supplementation with probiotics in the first 6 months of life did not protect against eczema and allergy in at-risk Asian infants: a 5-year follow-up. Int Arch Allergy Immunol. 2014;163:25-8.

83. Simpson MR, Dotterud CK, Storro O, et al. Perinatal probiotic supplementation in the prevention of allergy related disease: 6 year follow up of a randomised controlled trial. BMC Dermatol. 2015;15:13.

84. West CE, Hammarström ML, Hernell O. Probiotics in primary prevention of allergic disease - follow-up at 8-9 years of age. Allergy. 2013;68:1015-20.

85. Wickens K, Stanley TV, Mitchell EA, et al. Early supplementation with Lactobacillus rhamnosus HN001 reduces eczema prevalence to 6 years: does it also reduce atopic sensitization? Clin Exp Allergy. 2013;43:1048-57.

86. Cuello-Garcia CA, Brozek JL, Fiocchi A, et al. Probiotics for the prevention of allergy: A systematic review and meta-analysis of randomized controlled trials. J Allergy Clin Immunol. 2015;136:952-61.

87. Zuccotti G, Meneghin F, Aceti A, et al. Probiotics for prevention of atopic diseases in infants: systematic review and meta-analysis. Allergy. 2015;70;1356-71.

88. Fiocchi A, Burks W, Bahna SL, et al. Clinical Use of Probiotics in Pediatric Allergy (CUPPA): A World Allergy Organization Position Paper. World Allergy Organ J. 2012;5:148-

67.

89. Muraro A, Agache I, Clark A, et al. EAACl food allergy and anaphylaxis guidelines: managing patients with food allergy in the community. Allergy. 2014;69:1046-57.

90. Azad MB, Coneys JG, Kozyrskyj AL, et al. Probiotic supplementation during pregnancy or infancy for the prevention of asthma and wheeze: systematic review and meta-analysis. Bmj. 2013;347:f6471.

91. Bertelsen RJ, Brantsaeter AL, Magnus MC, et al. Probiotic milk consumption in pregnancy and infancy and subsequent childhood allergic diseases. J Allergy Clin Immunol. 2014;133:165-71 e1-8. 
${ }^{* *}$ In this large population-based Norwegian cohort study MoBa, the reported intake of probiotic milk products in pregnancy and infancy was associated with a reduced incidence of eczema and rhinocinjunctivitis, but not asthma, at 3 years of age.

92. Abrahamsson TR, Sinkiewicz G, Jakobsson T, et al. Probiotic lactobacilli in breast milk and infant stool in relation to oral intake during the first year of life. J Pediatr Gastroenterol Nutr. 2009;49:349-54.

93. Opoien HK, Valbo A, Grinde-Andersen A, et al. Post-cesarean surgical site infections according to CDC standards: rates and risk factors. A prospective cohort study. Acta obstetricia et gynecologica Scandinavica. 2007;86:1097-102.

94. Fiocchi A, Pawankar R, Cuello-Garcia C, et al. World Allergy Organization-McMaster University Guidelines for Allergic Disease Prevention (GLAD-P): Probiotics. World Allergy Organ J. 2015;8:4.

95. Guyatt GH, Oxman AD, Kunz R, et al. GRADE guidelines: 2. Framing the question and deciding on important outcomes. J Clin Epidemiol. 2011;64:395-400.

96. West CE, Prescott, S.L. Prebiotics and probiotics for prevention of allergic disease. In: UptoDate, Basedow D, eds. Waltham, MA: UptoDate, 2015. Available from: http://www.uptodate.com/contents/prebiotics-and-probiotics-for-prevention-of-allergicdisease. (Last accessed 10 October 2015).

97. West CE. Probiotics for allergy prevention. Benef Microbes. 2015 Dec 21:1-10, epub ahead of print.

98. Jackson DJ, Hartert TV, Martinez FD, et al. Asthma: NHLBI Workshop on the Primary Prevention of Chronic Lung Diseases. Ann Am Thorac Soc. 2014;11 Suppl 3:S139-45.

99. FAO/WHO. Guidelines for the evaluation of probiotics in food. Report of a Joint FAO/WHO Working Group on Drafting Guidelines for the Evaluation of Probiotics in Food. World Health Organization, London Ontario, Canada. 2002. 


\section{Figure 1:}

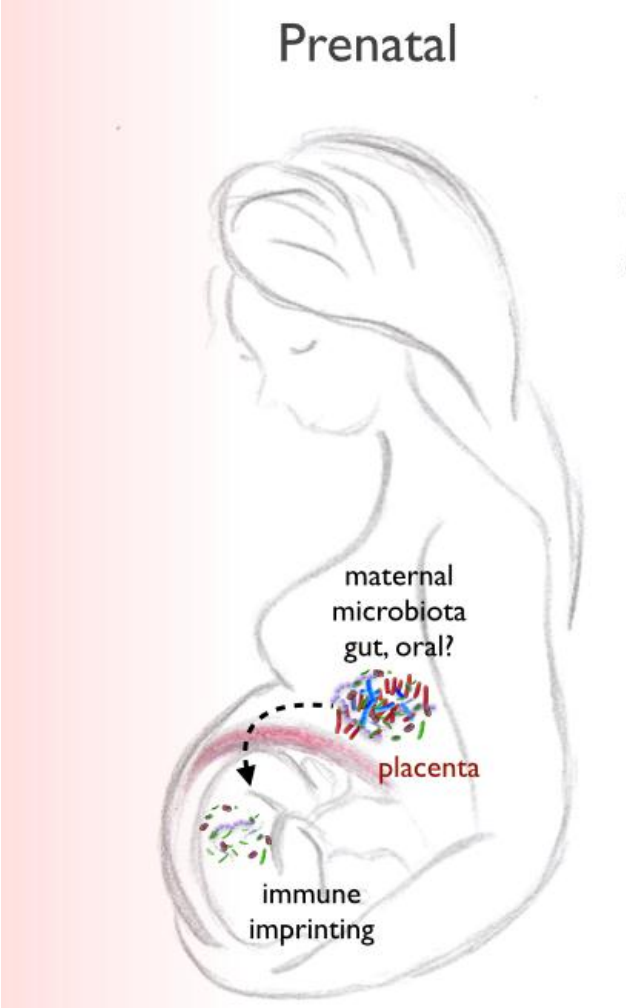

Delivery

Infancy

maternal microbiota gut, vaginal

Transmission of microbes from the mother to the fetus during pregnancy may provide the offspring with important microbes at birth, imprinting the microbiota and immune system in preparation for the much larger inoculum transferred during vaginal delivery and breastfeeding. "Heirloom" microbes received from the mother may be uniquely evolved to the offspring's genotype, increasing the chance for optimal mutualism. 
Table 1:

\begin{tabular}{|c|c|c|c|c|}
\hline $\begin{array}{l}\text { Study population } \\
\text { Probiotic(s) and dose } \\
\text { (References) }\end{array}$ & $\begin{array}{l}\text { Effect on } \\
\text { eczema }\end{array}$ & $\begin{array}{l}\text { Effect on } \\
\text { sensitization }\end{array}$ & $\begin{array}{l}\text { Effect on } \\
\text { respiratory } \\
\text { allergic } \\
\text { disease }\end{array}$ & $\begin{array}{l}\text { Effect on } \\
\text { objective } \\
\text { lung function } \\
\text { measures } \\
\end{array}$ \\
\hline \multicolumn{5}{|c|}{ MATERNAL ADMINISTRATION ONLY } \\
\hline $\begin{array}{l}\text { Any first degree relative with } \\
\text { allergic disease } \\
\text { L. rhamnosus GG } 1.8 \times 10^{10} \\
\text { CFU daily from } 36 \text { weeks } \\
\text { gestation until delivery- no } \\
\text { postnatal administration to } \\
\text { mother } \\
\text { Boyle et al, } 2011 \text { (68) }\end{array}$ & $\begin{array}{l}\text { No at } 1 \text { year } \\
\text { Long term } \\
\text { outcomes } \\
\text { not reported }\end{array}$ & No & No & Not \\
\hline $\begin{array}{l}\text { Unselected- about } 2 / 3 \text { with } \\
\text { family history of allergic } \\
\text { disease } \\
\text { L. rhamnosus GG, } \\
\text { L.acidophilus LA5, and } B \text {. } \\
\text { lactis Bb-12 ( } 5 \times 10^{10} \text { CFU of } \\
\text { each daily) from } 36 \text { weeks } \\
\text { gestation and then to } \\
\text { breastfeeding mother for } 3 \\
\text { months } \\
\text { Dotterud et al, } 2010 \text { (37) and } \\
\text { Simpson et al, } 2015 \text { (83) }\end{array}$ & $\begin{array}{l}\text { Reduced } \\
\text { cumulative } \\
\text { incidence of } \\
\text { eczema at } 2 \\
\text { and } 6 \text { years }\end{array}$ & No & & Not reported \\
\hline $\begin{array}{l}\text { Maternal allergic disease } \\
\text { L. rhamnosus LPR and } B \text {. } \\
\text { longum BL999 or L. paracasei } \\
\text { and } B \text {. longum BL } 9 \text {-each } \\
\text { probiotic at a daily dose of } 1 x \\
10^{9} \text { CFU from two months } \\
\text { before delivery and during two } \\
\text { months to breastfeeding } \\
\text { mother } \\
\text { Rautava et al, } 2012(40)\end{array}$ & $\begin{array}{l}\text { Reduction of } \\
\text { eczema at } 2 \\
\text { years in both } \\
\text { probiotic } \\
\text { groups } \\
\text { Long term } \\
\text { outcomes } \\
\text { not reported }\end{array}$ & No & $\begin{array}{l}\text { Not } \\
\text { reported }\end{array}$ & Not reported \\
\hline PERINATAL ADMINISTRATIC & TO MOTH & & & \\
\hline $\begin{array}{l}\text { Any first degree relative with } \\
\text { allergic disease } \\
\text { L. rhamnosus GG } 1 \times 10^{10} \text { CFU } \\
\text { daily given to mothers } 2-4 \\
\text { weeks before delivery and } \\
\text { then to breastfeeding mother } \\
\text { or directly to infant for } 6\end{array}$ & $\begin{array}{l}\text { Reduction of } \\
\text { eczema at } 2 \\
\text { years which } \\
\text { remained at } \\
4 \text { and } 7 \\
\text { years }\end{array}$ & No & No & No \\
\hline
\end{tabular}




\begin{tabular}{|c|c|c|c|c|}
\hline $\begin{array}{l}\text { months } \\
\text { Kalliomäki et al, } 2001 \text { (38), } \\
\text { Kalliomäki et al } 2003 \text { (75) and } \\
\text { Kalliomäki et al, } 2007 \text { (80) }\end{array}$ & & & & \\
\hline $\begin{array}{l}\text { Any first degree relative with } \\
\text { allergic disease } \\
\text { L. rhamnosus GG } 1 \times 10^{10} \text { CFU } \\
\text { daily given to mothers } 4-6 \\
\text { weeks before delivery and } \\
\text { then to breastfeeding mother } \\
\text { for } 3 \text { months or to infant for } 6 \\
\text { months } \\
\text { Kopp et al, } 2008(70)\end{array}$ & $\begin{array}{l}\text { No at } 2 \\
\text { years } \\
\text { Long term } \\
\text { outcomes } \\
\text { not reported }\end{array}$ & No & No & Not reported \\
\hline $\begin{array}{l}\text { Any first degree relative with } \\
\text { allergic disease } \\
\text { Mix of } L \text {. rhamnosus GG and } \\
\text { LC705 (both } 5 \times 10^{9} \text { ) and } B \text {. } \\
\text { breve Bb99 and } \\
\text { Proprionibacterium } \\
\text { freudenreichii ssp. shermani } \\
\text { JS (both } 2 \times 10^{9} \text { ) plus prebiotic } \\
\text { galacto-oligosaccharides; } \\
\text { given twice daily to mother } 2-4 \\
\text { weeks before delivery and } \\
\text { then to infant for } 6 \text { months } \\
\text { Kukkonen et al, } 2007 \text { (39) and } \\
\text { Kuitunen et al, } 2009 \text { (81) }\end{array}$ & $\begin{array}{l}\text { Eczema } \\
\text { reduction in } \\
\text { the probiotic } \\
\text { group at } 2 \\
\text { years } \\
\text { No eczema } \\
\text { reduction at } \\
5 \text { years }\end{array}$ & No & & $\begin{array}{l}\text { No differences } \\
\text { in FeNO } \\
\text { levels } \\
\text { between the } \\
\text { groups at } 5 \\
\text { years in a } \\
\text { randomized } \\
\text { subpopulation. }\end{array}$ \\
\hline $\begin{array}{l}\text { Any first degree relative with } \\
\text { allergic disease } \\
\text { L. reuteri } 1 \times 10^{8} \text { CFU daily 2- } \\
4 \text { weeks before delivery and } \\
\text { then to infant for } 12 \text { months } \\
\text { Abrahamsson et al, } 2007 \text { (36) } \\
\text { and Abrahamsson et al, } 2013 \\
\text { (77) }\end{array}$ & $\begin{array}{l}\text { No reduction } \\
\text { of eczema, } \\
\text { but reduction } \\
\text { of IgE- } \\
\text { associated } \\
\text { eczema in } \\
\text { the probiotic } \\
\text { group at } 2 \\
\text { years } \\
\text { No } \\
\text { difference } \\
\text { between the } \\
\text { groups at } \\
\text { the 7-year } \\
\text { follow up }\end{array}$ & No & No & $\begin{array}{l}\text { No differences } \\
\text { between the } \\
\text { groups when } \\
\text { evaluated by } \\
\text { spirometry } \\
\text { reversibility } \\
\text { test and } \\
\text { FeNO levels } \\
\text { at } 7 \text { years }\end{array}$ \\
\hline $\begin{array}{l}\text { Any first degree relative with } \\
\text { allergic disease } \\
\text { L. rhamnosus HN001 or } \\
\text { Bifidobacterium lactis (B. } \\
\text { lactis) HN019 } 1 \times 10^{10} \mathrm{CFU} \\
\text { daily from } 2-5 \text { weeks before }\end{array}$ & $\begin{array}{l}\text { Eczema } \\
\text { reduction in } \\
\text { the } \\
\text { L.rhamnosus } \\
\text { group at } 2 \\
\text { years which } \\
\text { remained }\end{array}$ & $\begin{array}{l}\text { Yes, lower } \\
\text { cumulative } \\
\text { prevalence of } \\
\text { sensitization } \\
\text { in the group } \\
\text { receiving } L \text {. } \\
\text { rhamnosus at }\end{array}$ & $\begin{array}{l}\text { Reduction } \\
\text { of allergic } \\
\text { rhinitis at } 4 \\
\text { years with } \\
\text { both } \\
\text { probiotics. }\end{array}$ & $\begin{array}{l}\text { No differences } \\
\text { between the } \\
\text { groups when } \\
\text { evaluated by } \\
\text { spirometry } \\
\text { reversibility } \\
\text { test and }\end{array}$ \\
\hline
\end{tabular}




\begin{tabular}{|c|c|c|c|c|}
\hline $\begin{array}{l}\text { delivery and then to infant } \\
\text { directly for } 2 \text { years } \\
\text { Wickens et al, } 2008(41) \text {, } \\
\text { Wickens et al } 2012(76) \text { and } \\
\text { Wickens et al, } 2013(85)\end{array}$ & $\begin{array}{l}\text { until } 6 \text { years } \\
\text { No benefit of } \\
B \text {. lactis }\end{array}$ & $\begin{array}{l}6 \text { years } \\
\text { No benefit of } \\
B \text {. lactis }\end{array}$ & $\begin{array}{l}\text { No } \\
\text { difference } \\
\text { between } \\
\text { the groups } \\
\text { in wheeze } \\
\text { or asthma }\end{array}$ & $\begin{array}{l}\text { FeNO levels } \\
\text { at } 6 \text { years }\end{array}$ \\
\hline $\begin{array}{l}\text { Maternal allergic disease in } \\
\sim 80 \% \text { of the study population } \\
\text { L. rhamnosus GG and } B \text {. lactis } \\
\mathrm{Bb}-121 \times 10^{10} \mathrm{CFU} \text { daily from } \\
\text { first trimester and then to } \\
\text { breastfeeding mother until } \\
\text { cessation of exclusive } \\
\text { breastfeeding } \\
\text { Huurre et al, } 2008(74)\end{array}$ & $\begin{array}{l}\text { No } \\
\text { Long term } \\
\text { outcomes } \\
\text { not reported }\end{array}$ & $\begin{array}{l}\text { No, but } \\
\text { reduced } \\
\text { sensitization } \\
\text { in infants of } \\
\text { sensitized } \\
\text { mothers at } 1 \\
\text { year in a } \\
\text { subgroup } \\
\text { analysis. }\end{array}$ & $\begin{array}{l}\text { Not } \\
\text { reported }\end{array}$ & Not reported \\
\hline $\begin{array}{l}\text { Allergic disease of either } \\
\text { parent and in at least one } \\
\text { sibling } \\
\text { Lactococcus lactis W58, B. } \\
\text { lactis W52 and B. bifidum W23 } \\
1 \times 10^{9} \text { CFU each daily six } \\
\text { weeks before delivery and } \\
\text { then directly to infant for } 12 \\
\text { months } \\
\text { Niers et al, } 2009(71) \text { and } \\
\text { Gorissen et al, } 2014(78)\end{array}$ & $\begin{array}{l}\text { Reduced } \\
\text { cumulative } \\
\text { incidence of } \\
\text { eczema in } \\
\text { the first } \\
\text { three } \\
\text { months of } \\
\text { life } \\
\text { No } \\
\text { difference } \\
\text { between the } \\
\text { groups at } \\
\text { the 6-year } \\
\text { follow up }\end{array}$ & No & & Not reported \\
\hline $\begin{array}{l}\text { Any first degree relative with } \\
\text { allergic disease } \\
\text { B. bifidum BGN4, B. lactis } \\
\text { AD011, and } L \text {. acidophilus } \\
\text { AD031( } 1.6 \times 10^{9} \text { CFU of each } \\
\text { daily) } 4-8 \text { weeks before } \\
\text { delivery, } 3 \text { months to } \\
\text { breastfeeding mother and then } \\
\text { to infant from } 4 \text { to } 6 \text { months } \\
\text { Kim et al, } 2010(69)\end{array}$ & $\begin{array}{l}\text { Reduced } \\
\text { cumulative } \\
\text { incidence } \\
\text { and } \\
\text { prevalence } \\
\text { of eczema at } \\
12 \text { months } \\
\text { Long term } \\
\text { outcomes } \\
\text { not reported }\end{array}$ & Not reported & $\begin{array}{l}\text { Not } \\
\text { reported }\end{array}$ & Not reported \\
\hline $\begin{array}{l}\text { Maternal allergic disease } \\
\text { L. rhamnosus GG } 1 \times 10^{10} \\
\text { CFU daily from second } \\
\text { trimester and then } 6 \text { months to } \\
\text { mother if breastfeeding or } \\
\text { directly to infant }\end{array}$ & $\begin{array}{l}\text { No } \\
\text { Long term } \\
\text { outcomes } \\
\text { not reported }\end{array}$ & No & No & Not reported \\
\hline
\end{tabular}




\begin{tabular}{|c|c|c|c|c|}
\hline \multicolumn{5}{|l|}{ Ou et al, 2012 (72) } \\
\hline $\begin{array}{l}\text { Any first degree relative with } \\
\text { allergic disease } \\
\text { L. salivaris CUL61, L. } \\
\text { paracasei CUL08, } B \text {. animalis } \\
\text { ssp lactis CUL34 and } B \text {. } \\
\text { bifidum CUL20, } 10^{10} \text { CFU daily } \\
\text { in total starting } 2-4 \text { weeks } \\
\text { before delivery and the to } \\
\text { infant for six months } \\
\text { Allen et al, } 2014(67)\end{array}$ & $\begin{array}{l}\text { No reduction } \\
\text { of eczema, } \\
\text { but a } \\
\text { reduction of } \\
\text { lgE- } \\
\text { associated } \\
\text { eczema at } 2 \\
\text { years in the } \\
\text { probiotic } \\
\text { group } \\
\text { Long term } \\
\text { outcomes } \\
\text { not reported }\end{array}$ & Not reported & No & Not reported \\
\hline \multicolumn{5}{|l|}{ POSTNATAL ADMINISTRATION } \\
\hline $\begin{array}{l}\text { Maternal allergic disease } \\
\text { L. acidophilus (LAVRI-A1) } 3 x \\
10^{8} \text { CFU given within } 48 \\
\text { hours, and then for six } \\
\text { months, directly to infant } \\
\text { Taylor et al, } 2007 \text { (66) and } \\
\text { Jensen et al, } 2012 \text { (79) }\end{array}$ & $\begin{array}{l}\text { No reduction } \\
\text { at } 1 \text { year nor } \\
\text { at the } 5 \text { year } \\
\text { follow-up }\end{array}$ & $\begin{array}{l}\text { No } \\
\text { Sensitization } \\
\text { more } \\
\text { common in } \\
\text { the probiotic } \\
\text { group at } 1 \\
\text { year, but not } \\
\text { at the later } \\
\text { follow-ups }\end{array}$ & & Not reported \\
\hline $\begin{array}{l}\text { Any first degree relative with } \\
\text { allergic disease } \\
\text { L. rhamnous LPR } 1 \times 10^{9} \text { CFU } \\
\text { and B. longum (BL999) } 6 \times 10^{8} \\
\text { CFU daily to infant (in infant } \\
\text { formula) for } 6 \text { months } \\
\text { Soh et al, } 2009 \text { (65) and Loo } \\
\text { et al, } 2014(82)\end{array}$ & $\begin{array}{l}\text { No reduction } \\
\text { at } 2 \text { or } 5 \\
\text { years }\end{array}$ & No & No & Not reported \\
\hline $\begin{array}{l}\text { Mixed (2/3 with at least one } \\
\text { first grade relative with allergic } \\
\text { disease) } \\
\text { L paracasei ssp paracasei } \\
\text { F19 } 1 \times 10^{9} \text { CFU daily to infant } \\
\text { (in infant cereal) during } \\
\text { weaning from } 4-13 \text { months } \\
\text { West et al, } 2009 \text { (73) and } \\
\text { West et al, } 2013(84)\end{array}$ & $\begin{array}{l}\text { Reduced } \\
\text { cumulative } \\
\text { incidence of } \\
\text { eczema at } \\
13 \text { months } \\
\text { No } \\
\text { difference } \\
\text { between the } \\
\text { groups at } \\
\text { the 8-year } \\
\text { follow up }\end{array}$ & No & No & $\begin{array}{l}\text { No differences } \\
\text { between the } \\
\text { groups when } \\
\text { evaluated by } \\
\text { spirometry } \\
\text { reversibility } \\
\text { test and } \\
\text { FeNO levels } \\
\text { at } 8 \text { years }\end{array}$ \\
\hline
\end{tabular}

CFU- colony-forming units; FeNO- fractional exhaled nitric oxide; IgE- Immunoglobulin E 
The table was modified from West C.E. Probiotics for allergy prevention. Benef Microbes, in press (ref 97). 